\section{Health in Brazil: examples for the world}

\section{Saúde no Brasil: exemplos para o mundo}

Malaquias Batista Filho 1

Anete Rissin 2
1-2 Instituto de Medicina Integral Prof. Fernando Figueira. Rua dos Coelhos, 300. Boa Vista. Recife, PE, Brasil. CEP: 50.070-550. E-mail: malaquias.imip@gmail.com

\begin{abstract}
In the year 2012, for the first time in the history of humanity, the urban population has exceeded the rural population. This change has been conditioned, in large part, by migratory flows in the direction of the field to the cities, singularizing the importance of the situation according to epidemiological, ecological, political, and social aspects. These issues are highlighted by the United Nations (UNICEF and WHO) especially considering the remarkable and growing relevance that the poverty condition of rural families exercises in this displacement, creating a remarkable adverse and conflictive environment, mainly in the health sector. This fact occurs because the infrastructure of urban services is not keeping up with the sprawls in the outskirts of the cities of medium and large sizes.

These arguments, of universal character, assume a crucial importance in developing countries, as in the case of Brazil, Latin America, an Asian subcontinent and the greater part of Africa. It is a context that justifies the I Brazilian Workshop on the Health of Subnormal Urban Clusters (old slums) to be held in Recife, as a strategy to consolidate a basic information framework about the epidemiological scenario, the supply and demand for health care services in urban areas of poverty. With an propositional objective: establish an agenda for research and intervention models having as focus the priorities of health of these urban spaces submitted to socio-economic conditions of recognized vulnerability.
\end{abstract}

Key words Poverty areas, Health, Developing countries, Brazil

\section{Resumo}

O fato de que, a partir de 2012, pela primeira vez na história da humanidade a população urbana tenha ultrapassado a população rural, e que esta mudança tenha sido condicionada, em grande parte, por correntes migratórias no sentido campo/cidade, singulariza a importância dessa situação em termos epidemiológicos, ecológicos, politicos e sociais. São estes os aspectos destacados pelas Nações Unidas (UNICEF e OMS) considerando sobretudo a marcante e crescente relevância que a condição de pobreza das familias rurais exerce neste deslocamento espacial, criando um ambiente notavelmente adverso e conflitivo, principalmente para o setor saúde, desde que a infraestrutura de serviços urbanos não acompanha o ritmo de ocupação desordenada nas periferias das cidades de médio e grande porte.

Estes argumentos, de caráter universal, assumem uma importância crucial nos países em desenvolvimento, como no caso do Brasil, da América Latina, do subcontinente asiático e da maior parte da África. É um contexto que justifica o I Workshop Brasileiro sobre Saúde de Aglomerados Urbanos Subnormais (favelas) a ser realizado no Recife, como estratégia para consolidar um quadro de informações básicas sobre o cenário epidemiológico, a oferta e a demanda de serviços de saúde em áreas de pobreza urbana. $O$ evento terá como objetivo propositivo o estabelecimento de uma agenda de estudos e modelos de intervenção com enfoque nas prioridades de saúde desses espaços urbanos, submetidos a condições socioeconomicas de reconhecida vulnerabilidade.

Palavras-chave Áreas de pobreza, Saúde, Países em desenvolvimento, Brasil 


\section{Introduction}

It is a common conduct - almost standard practice in the field of health - to establish ten-year timeframes for international accords and, more specifically, to adopt standardized strategies, justifying the proposed aims or outcomes quantified in time and space. The aim in fact is to consolidate multilateral government healthcare principles and practices. Political motives, common and overlapping epidemiological concerns, as in the case of infectious diseases, or, much more justifiably, ethical reasons grounded in the doctrine of human development guide and confer legitimacy on this practice.

These are the historical motives and antecedents for the creation and expanding remit of the World Health Organization (WHO) or the former International Children's Emergency Fund, which is currently known as the United Nations Children's Fund (UNICEF), as well as the various agencies that, in a more restricted and specific setting, deal with clearly defined issues, such as the ethics of research involving human beings, the production, sale and use of medicine by laypeople or health workers, environmental health, and many others. It is in the name of these topical issues that we are periodically summoned to technical meetings or formal assemblies of high-ranking government officials and delegates with the responsibility of institutionalizing decisions that require the commitment of governments, when, beyond formal adherence to accords, signatory countries are legally bound to put them into practice. Generally speaking, this is the format followed by summit meetings, which are almost always held under the auspices of the richer and more powerful nations.

However, the unpredictability of today's world is teaching us new lessons. Thus, the precursors of the Ten-Year Plan for Mother and Child Health for 1990-2000 did not come from the teaching, research and outreach institutions of more developed nations, which are the traditional seats of expertise in world health. These new alternatives for guiding the desired outcomes of the future, at the level of collective health, arose from the combined efforts of and mutual support for policies and programs in poor countries, such as Sri Lanka, Thailand, Chile, Cuba, Costa Rica, Grenada, Malaysia, and the southern Indian province of Kerala, all at that time with a per capita income of under US\$6,000, or, $15 \%$ of the average among rich nations. The case of Cuba is an intriguing one, since this country compared (as it still does today) favorably in terms of health indicators with the United States - the richest and most powerful nation in the world, with the most advanced range of technical and scientific knowledge. The international renown of the Cuban experience has been such that the WHO has made Havana the permanent host for the biennial International Primary Healthcare Conference.

It is heartening to note that, since 2010, the world has come to view healthcare in Brazil in a new light, especially so far as policy options and strategic decisions are concerned. There is extensive evidence of this. Two years ago, for example, one of the most prestigious and traditional scientific periodicals in the world (The Lancet) dedicated a special issue to health research and programs in Brazil, taking the Brazilian National Health System (SUS) as a point of reference. 1 The epidemiological transition that is underway in Brazil is a process that has been noted worldwide. However, while, in more developed nations, the great change in the profiles of morbidity and mortality occurred as part of an 80- to 100-year cycle, in Brazil, it took place within the course of little more than a quarter of a century (1974-2000). It is true that this is a mixed scenario, with infectious diseases and diseases of poverty coexisting with chronic non-communicable diseases. However, at the rate things are happening, within a few years it is expected that stuntedness among Brazilian children will be under control and will cease to be a public health problem. ${ }^{2}$ Practically in lockstep with the drop in Protein Energy Malnutrition among children, there has been the emergence of the worldwide epidemic of obesity/overweight in people of all ages. In the past 35 years, since 1974/75, we have been rapidly reaching the levels already achieved by countries deemed developed: a life expectancy close to 80 years, infant and maternal mortality in sharp decline, avoidable and curable diseases and causes of death under control and a "decline" in mortality related to chronic non-communicable diseases.

However, along with this epidemiological profile, the most striking feature of the recent history of healthcare in Brazil has been creativity, with innovations both in terms of theory and health strategies. Paulo Gadelha, an expert in sanitary medicine from the Oswaldo Cruz Foundation (Fiocruz), notes that there have been surprising changes in the way healthcare is viewed and managed in Brazil. The National Health System derived its legitimacy from a series of national conferences that mobilized the general public, democratized its proposals and achievements, and became a major policy legacy of the 1988 Constitution. Seen as a utopia in its early stages, the SUS now stands as an example for the whole world, to the extent that Michel Marmot, the 
renowned epidemiologist, who specializes in the study of health inequalities, recommends that researchers from around the world learn Portuguese so as to be able to acquire more direct knowledge of the Brazilian experience. This is a highly significant remark, given that Marmot's own country, the United Kingdom, has long set the standard in terms of excellence in public health policy. In fact, various factors have brought the Brazilian experience to the attention of the world, including the WHO declaration that one of the main contributions to the enormous reduction in infant mortality around the world has been that of the Brazilian Human Milk Banks, which have been copied by various nations. Mention should also be made of a study conducted by the Institute of Applied Economic Research that ranks Brazil first among a group of 32 nations, including some developed ones, in terms of the efficiency (that is cost-effectiveness) of healthcare management.

The Family Health Program (PSF), now known as the Family Health Strategy (ESF) started out with IMIP/UNICEF's experiences working in slums in the city of Recife and, within the course of two decades, has spread to every municipality in Brazil and now serves a population of 100 million. It was the visibility of such initiatives in the field of basic healthcare outreach programs, with a participatory, multidisciplinary philosophy, firmly grounded in the principles of reducing inequality, and promoting equity and universal care as civil rights, which led the Brazilian government at the request of the WHO, to hold the World Conference on the Social Determinants of Health in Rio de Janeiro in 2011.

Forming part of the same body of ideas and movements, the Brazilian National Food Security Policy has become a model worldwide, especially in Africa and Latin America. Focusing once again on the issue of poverty and inequality, the Brazilian proposal, whose national forum, the Food Security Council (CONSEA) is the place where proposals are put forward, policy is legitimized and two-thirds of the collegiate body represents civil society, works with 45 million direct beneficiaries (Family Support Program) and serves 35 million school-aged children. The rich and varied national experience in the field of food security and nutrition was a decisive factor in the election of the president of the CONSEA as President of the Executive Council of the Food and Agriculture Organization (FAO), in Rome.

The ideas underlying these events are worth spelling out. These include the belief that health should incorporate the issue of human development into its main objectives and strategies, and accord the status of prerequisites and co-requisites to employment, income, education, politics, green issues, co-participation, housing, ethics and all facets of sustainability. Brazil, which is known to be one of the most unequal countries in the world, is correcting the structural distortions inherited from its history. Thus, in the past ten years, the minimum wage has increased from a little over US $\$ 60$ to over US\$330, considerably boosting the purchasing power of the poorest families. Nowadays, the middle classes number 104 million individuals with a per capita family income of between R \$ 291 and R\$ 1,019, according to a commission set up by the President of the Republic's Secretary for Strategic Affairs (SAE). This middle class now represents $54 \%$ of the Brazilian population. ${ }^{3}$

This fact alone has had a striking impact on health, improving diet, housing, the level of education, access to primary goods and services, the adoption of new lifestyles, the promotion of women's health at work, and the enhancement of women's "status" in the family and society. This is evidently a new situation that has resulted in an internationally renowned experience and set an example, politically and culturally, not only for developing nations, but even for those deemed to be developed. It was in the light of this that, in 2011, Brazil held the World Conference on the Social Determinants of Health (CMDSS), along with two other major international events, with the assistance of the WHO: Health Technology Assessment International, ${ }^{4}$ hosted for the first time by Brazil, culminating in the installation of the South American Institute of Health Governance, 5 which consolidates Brazil's central position in this field, under the watchful eye of the president of the Oswaldo Cruz Foundation. It is in acknowledgement of this continuing role that Brazil has planned, ten years in advance, the Brazil Health 2022-2030 project - showing a forwardlooking vision and a commitment to meet the challenges of the coming decades.

It cannot be said that Brazil has solved all of its problems. The world is full of demands that have not yet been met. But, considering the epidemiological and administrative chaos that prevailed until only a short while ago, what has been achieved in many fields of collective health has restored the self-esteem, the spirit of leadership and, above all, the conviction that we can make history by setting a good example.

All these questions arise from the need for wide dissemination of these issues in publications, which is the role played by scientific journals in the field of health, especially collective health. 


\section{References}

1. Victora CG, Leal MC, Barreto ML, Schmidt MI, Monteiro CA, orgs. Saúde no Brasil: a série "The Lancet”, 2011. Rio de Janeiro: Editora Fiocruz; 2011.

2. Monteiro CA, Benício MHD, Konno SC, Silva ACF, Lima ALL, Conde WL. Causas do declínio da desnutrição infantil no Brasil, 1996-2007. Rev Saúde Pública. 2009; 43: 35-43.

3. Folha de São Paulo. Classe média tem renda per capita de R\$ 291 a R\$ 1.019, diz governo. 2012. [Accessed on $18 \mathrm{fev}$ 2013]. Available at: http://www1.folha.uol.com.br/ mercado/1097561-classe-media-tem-renda-per-capita-de-r291-a-r-1019-diz-governo.shtml
4. Brasil. Ministério da Saúde. Encontro anual da Sociedade Health Technology Assessment International (HTAi), Brasil, 2011. Available at: Rev Saúde Pública. 2011; 45 (6).

5. Instituto Sul-americano de Governo em Saúde. Sobre o Instituto Sul-americano de Governo em Saúde (ISAGS). 2011. [Accessed on $19 \mathrm{fev}$ 2013]. Available at: http://www.isags-unasursalud.org/interna.asp?lang=1\&idAr ea $=1 \&$ idSubArea $=34$

Recebido em 26 de dezembro de 2012

Versão final apresentada em 14 de janeiro de 2013

Aprovado em 21 de janeiro de 2013 